\title{
A REPRESENTAÇÃO DA TORTURA EM DOIS CONTOS DE JÚLIO CÉSAR MONTEIRO MARTINS: “O MÉTODO” E “A POSIÇÃO”
}

\author{
[The Representation of Torture in Two Short-Stories by Júlio César \\ Monteiro Martins: "O Método" and "A Posição"]
}

\begin{abstract}
Arnaldo Franco Junior ${ }^{1}$
Resumo: Nos contos “O método" e "A posição", produzidos nos anos 70 do séc. XX, o escritor Júlio César Monteiro Martins (1955-2014) explora o motivo da tortura, denunciando-a como prática banalizada no horizonte repressivo criado pela ditadura civil-militar implantada no Brasil a partir de 1964 . Neste artigo, faremos uma leitura crítica dos dois contos, cotejando-os para refletir sobre a problemática da representação da violência extrema na literatura e suas implicações estéticas e éticas.

Palavras-chave: Conto; Júlio César Monteiro Martins; Representação; Tortura; Violência.
\end{abstract}

Abstract: In the short stories "O método" and "A posição", produced in the 70's, the writer Júlio César Monteiro Martins (1955-2014) explores the theme of torture, denouncing it as a trivialized practice in the repressive horizon created by the civil-military dictatorship implanted in Brazil since 1964. In this article, we will make a critical reading of the two short stories, comparing them to reflect on the problem of the representation of extreme violence in literature and its aesthetic and ethical implications.

Keywords: Júlio César Monteiro Martins; Representation; Short-story; Torture; Violence.

1 Professor do Departamento de Estudos Lingüísticos e Literários - Universidade Estadual Paulista "Júlio de Mesquita Filho” - UNESP - 15054-000 - São José do Rio Preto - SP - Brasil. E-mail: arnaldo.franco-junior@unesp.br 


\section{INTRODUÇÃO}

Júlio César Monteiro Martins (1955 - 2014) é um escritor da geração que, estreando nos anos 60-70 do séc. XX, enfrentou o adverso contexto de violência e repressão políti$\mathrm{ca}$, censura às artes e à imprensa criado pela ditadura civil-militar implantada no Brasil a partir de 1964. Literariamente, ele se vincula à geração de Caio Fernando Abreu, Luiz Fernando Emediato, Domingos Pellegrini Jr., Jefferson Ribeiro de Andrade e Antonio Barreto, com os quais dividiu a antologia Histórias de um novo tempo - o novíssimo conto brasileiro, publicada pela Codecri, editora do jornal O Pasquim, em 1977.

Residindo na Itália a partir de 1994, o escritor desenvolveu a sua carreira publicando tanto lá quanto aqui. No Brasil, seus livros mais conhecidos são: Torpalium (1977), Sabe quem dançou? (1978), A oeste de nada (1981), Muamba (1985), O espaço imaginário (1987). Além disso, participou das antologias: O erotismo no conto brasileiro (Brasil, 1980), Histórias de amor infeliz (Brasil, 1985), Um prazer imenso (Brasil, 1986), Fora da ordem e do progresso (Brasil, 2004).

De sua produção inicial, vamos aqui estudar "O método" e "A posição", contos em que o motivo da tortura se destaca, ganhando duas diferentes abordagens literárias que, quando comparadas, nos levam a pensar sobre a problemática vinculada à representação da violência extrema na literatura e nas artes.

\section{“O MÉTODO” E OS RISCOS DO APELO AO SENSACIONAL}

O conto "O método" faz parte do livro Histórias de um novo tempo - O novíssimo conto brasileiro, coletânea publicada em 1977 e um dos grandes sucessos editoriais da editora Codecri, vinculada a $O$ Pasquim, grande sucesso da chamada imprensa nanica na década de 70 do séc. XX. Nessa coletânea, o conto é datado de 13 de abril de 1976. Foi escrito, portanto, já sob a abertura política promovida, sob a tutela da ditadura civil-militar, entre 1975 e 1985.

"O método" narra uma sessão de tortura que resulta no assassinato brutal de uma jovem por três homens num porão do que, por efeito de sugestão, é, talvez, uma instituição prisional. Regina, a vítima, é uma jovem de 17 anos, e seus algozes são três homens que, por sugestão do texto, são torturadores profissionais. Levada ao porão pelos três, a jovem é amordaçada e amarrada, sem calcinha, com as pernas abertas, e, depois, torturada com uma cobra, que, agredida pelos homens, entra-lhe pela vagina e se aninha em seus intestinos, matando-a enquanto os torturadores gargalham.

O conto evidencia o investimento que parte da produção literária brasileira dos anos 70, já sob a abertura política, fez na explicitação realista-naturalista para representar a violência urbana e, também, a violência e o terrorismo de estado. Pela ultraviolência, marcada pela ênfase na descrição do método utilizado para torturar e assassinar a jovem, o conto atinge em cheio o que Antonio Candido identifica, em "A nova narrativa" (1989) como o objetivo de causar um choque no leitor. Segundo o crítico, na nova narrativa: 
"O ímpeto narrativo se atomiza e a unidade ideal acaba sendo o conto, a crônica, o sketch, que permitem manter a tensão difícil da violência, do insólito ou da visão fulgurante.

Ao mesmo tempo, nos vemos lançados numa ficção sem parâmetros críticos de julgamento. Não se cogita mais de produzir (nem de usar como categorias) a Beleza, a Graça, a Emoção, a Simetria, a Harmonia. O que vale é o Impacto, produzido pela Habilidade ou a Força. Não se deseja emocionar nem suscitar a contemplação, mas causar choque no leitor e excitar a argúcia do crítico, por meio de textos que penetram com vigor mas não se deixam avaliar com facilidade.

Talvez, por isso, caiba refletir, para argumentar, sobre os limites da inovação que vai se tornando rotineira e resiste menos ao tempo. Aliás, a duração parece não importar à nova literatura, cuja natureza é freqüentemente a de uma montagem provisória em era de leitura apressada, requerendo publicações ajustadas ao espaço curto de cada dia. Dentro desta luta contra a pressa e o esquecimento rápido, exageram-se os recursos, e eles acabam virando clichês aguados nas mãos da maioria, que apenas segue e transmite a moda". (CANDIDO, 1989, p. 214).

Vejamos como se dá a construção deste efeito de choque em "O método". Em seu primeiro parágrafo, o conto nos apresenta Regina, a vítima, encarcerada:

Os três homens empurraram Regina escada abaixo e deixaram-na sozinha durante alguns minutos numa sala subterrânea, ou porão espaçoso. Das paredes negras e nuas brotavam manchas esverdeadas de limo. Os cantos do salão não eram atingidos pela débil luz central e pareciam esconder pequenas feras. Quatro colunas finas sustentavam o teto. Na mais próxima à lâmpada eram vistos alguns corpos nus desenhados, dois corações flechados e a frase "mamãe, eu te amo" (MARTINS, 1977, p. 19).

A narrativa começa in media res, modo de sugerir que a curta sequência de ação que constituirá a história narrada no conto é a fase final de um processo anterior de aprisionamento: "Os três homens empurraram Regina escada abaixo e deixaram-na sozinha [...] numa sala subterrânea, ou porão espaçoso" (MARTINS, 1977, p. 19). O motivo da violência já se manifesta em "empurraram [...] escada abaixo", articulando-se com a descrição de um espaço fechado que remete à ideia de prisão.

A caracterização do espaço subterrâneo é lúgubre: espaçoso, iluminado por uma "débil luz central", com paredes "negras e nuas" manchadas de limo, sustentado por "Quatro colunas finas". Por meio da caracterização dos cantos da sala subterrânea, que "pareciam esconder pequenas feras", e dos "corpos nus", dos "corações flechados" e da frase "mamãe, eu te amo" inscritos numa das colunas, o narrador reforça o motivo da violência. Estes elementos funcionam como índices do horror que caracterizará o supliciamento da jovem Regina pelos três algozes, além de reforçarem a sugestão de que se trata de um espaço para- 
-institucional vinculado a uma prisão: uma câmara de tortura subterrânea.

À caracterização da situação dramática no $1^{\circ}$ parágrafo segue-se uma caracterização dos torturadores entremeada com o início da descrição da tortura:

Dos três homens que retornam, munidos de uma lanterna, um par de luvas de operário, uma caixa de madeira e uma corda, apenas um havia trocado palavras com Regina anteriormente. Exatamente o que parecia ser o mais velho, careca e de bigodes. Havia perguntado sua idade. Dezessete, disse a moça. Falou algumas obscenidades também, que ficaram sem resposta. Eles agora riem enquanto descem, e o bafo azedo de suor e pinga se mistura ao cheiro de mofo.

O careca tira a camisa, estende-a sobre o chão, senta-se sobre ela de pernas cruzadas e acende um cigarro. Um outro calça as luvas. O terceiro arrasta Regina para a coluna mais próxima e a amarra fortemente, sentada no chão. Retira do bolso uma estopa, que é empurrada entre seus dentes, e finaliza amordaçando-a com a perna de uma calça (MARTINS, 1977, p. 19-20).

As personagens são caracterizadas por breves traços que as identificam como tipos: Regina, jovem de dezessete anos, é a vítima; os homens que a subjugam são os algozes anônimos que têm poucos traços físicos: o mais velho é careca e tem bigode; o segundo usa luvas; do terceiro nada se sabe além das ações que realiza. Eles riem enquanto levam a moça para o subterrâneo, exalando cheiro de suor e pinga. A divisão binária entre vítima e algozes acirra, no conflito dramático, o motivo da violência porque o apoia sobre outras divisões binárias: fraco $\mathrm{X}$ forte (um contra três), mulher $\mathrm{X}$ homem, jovem $\mathrm{X}$ adultos. Tudo isso concorre para que, dado o desenvolvimento da ação dramática que destaca o método empregado na tortura e no assassinato da vítima, afirme-se um triunfo do vício sobre a inocência (três viciosos homens sádicos adultos contra uma adolescente frágil e inexperiente), uma vitória, enfim, do mal contra o bem. Por um lado, isto potencializa o impacto de choque do conto em razão da exacerbação conferida à violência descrita, fazendo com que o leitor experimente o espanto e o horror diante do que lê - sobretudo se contextualizar historicamente o conto. Por outro lado, e considerando-se o fato de que a concisão que reduz a descrição da ação dramática a elementos mínimos produz um efeito de descontextualização espaçotemporal, o choque produzido pela descrição da tortura pode suscitar uma leitura da violência representada no conto como um fim em si mesmo, favorecendo uma recepção perversa afeita ao sadismo. Observe-se:

O careca então se ergue, aproxima-se da garota com o cigarro entre os dentes arreganhados, num ar de deboche, levanta seu vestido e retira lentamente a calcinha dizendo: "Fica quieta, sua putinha, que eu conheço uma baranga lá na zona que daria tudo para estar no seu lugar". Os outros se estufam de rir. Os olhos de Regina mergulham sobre sua face lívida.

$\mathrm{O}$ velho se afasta. $\mathrm{O}$ das luvas abre a caixa de madeira e retira com cuidado uma 
cobra surucucu de dorso amarelo-escuro e aproximadamente um metro e meio de comprimento. A cobra é suspensa como um troféu, para que todos a vissem bem e ovacionassem como bárbaros. $\mathrm{O}$ tal que a havia amarrado, sentou-se sobre sua perna direita e empurrou com os pés e mãos a perna esquerda, abrindo um vão irreversível.

O das luvas sacode a surucuru, retorcendo-a e gritando: "Fica nervosinha, sua puta! Fica louca, sua viada! Espuma, seu demônio!” A cobra se enroscava e desenroscava com enorme rapidez, irritada, ou, talvez, amedrontada. As luvas estrangulavam seu corpo grosso como vela de sacristia. O ofídio vibrava elétrico.

Após a excitação, o animal foi deitado ao chão, entre as pernas de Regina, com a cabeça voltada para o oásis de pelos que circundava seu poço ainda virgem.

Os dedos do homem se abriram e a cobra, solta, procurou passagem para a toca possível, onde pudesse ficar oculta de seu estrangulador (MARTINS, 1977, p. 20-21).

Os termos "garota" e "virgem" e o riso dos homens destacam, pelo acirramento das polaridades binárias acima descritas, a condição de vítima inocente de Regina e a monstruosidade sádica de seus algozes. A ausência de elementos que se prestem a uma contextualização histórica mais precisa da ação dramática confere atualidade à história narrada, mas, exatamente por isto, instala-se no horizonte da leitura a possibilidade incômoda da recepção perversa. Desconsiderados os vínculos do conto com a violência de estado realizada durante a ditadura civil-militar no Brasil, ele pode perigosamente ser lido como conto de terror esvaziado de conteúdo crítico. O método que ele pretende denunciar como prática sistemática de tortura que se exacerbou a ponto de vitimar inocentes, tornando-se, por vezes, divertimento de sádicos protegidos pelo aparato institucional e/ou para-institucional ligado à repressão política e ao terrorismo de estado ${ }^{2}$, pode, em razão da ausência de elementos que favoreçam a contextualização histórica, esvaziar o efeito de choque de suas funções crítica e política.

Pode-se argumentar que a ação e os efeitos da censura explicam, parcial ou integralmente, esta ausência de elementos capazes de contextualizar de modo mais efetivo o sen-

2 Em 19 de agosto de 2014, a jornalista Mirian Leitão revelou, em depoimento ao jornalista Luiz Cláudio Cunha do site Observatório da Imprensa, ter sido torturada, nua e grávida, com uma cobra durante sua prisão na ditadura civil-militar: "Fiquei presa ali, no $38^{\circ}$ Batalhão. Os torturadores vieram de fora e, depois, sumiram. Eles trouxeram a cobra. Eu lembro que chamavam o pior dos torturadores, o dono da cobra, de Dr. Pablo. // Dr. Pablo era o codinome de um dos mais truculentos oficiais do DOCI-CODI do II Exército, na Rua Barão de Mesquita, no bairro carioca da Tijuca: Paulo Malhães, coronel do Centro de Informações do Exército (CIE)" (CUNHA, 2014, s/p. - grifos no original). A cineasta Lúcia Murat, em reportagem do jornalista Daniel Fávero, contou: "Me puseram de novo no pau de arara. Mais espancamento, mais choque, mais água e dessa vez entraram as baratas. Puseram baratas passeando pelo meu corpo, colocaram uma barata na minha vagina. Hoje parece loucura, mas um dos torturadores, de nome de guerra Gugu, tinha uma caixa onde ele guardava as baratas amarradas por barbantes e através do barbante ele conseguia manipular as baratas pelo meu corpo" (FAVERO, 2014, s/p.). O depoimento de Murat, bem como de outras mulheres torturadas, encontra-se também no artigo "Violações dos direitos humanos das mulheres na ditadura", de Maria Amélia de Almeida Teles (2015). 
tido crítico do conto. Sob o risco da censura e de tornar-se vítima da violência do aparato repressor mobilizado pela ditadura para neutralizar e, por vezes, exterminar os adversários, muitos escritores e artistas deslocaram para o contexto sócio-histórico e político imediato de recepção de suas obras a função de completar e dar acabamento ao sentido daquilo que nelas é sugerido, entredito ou não-dito. Isto, porém, embora possa constituir-se numa explicação válida, não impede que, no caso deste conto, a possibilidade de uma recepção perversa se instale no horizonte da recepção. Concorre para isso a circunscrição da tortura representada no conto sob o signo da monstruosidade. Sua violência é tão exacerbada que beira o absurdo, revelando que o conto se instala no fio da navalha entre o propósito de constituir-se como literatura de denúncia politicamente engajada na crítica às atrocidades da ditadura civil-militar e o risco de reduzir-se a narrativa de terror que faz da ultraviolência um divertimento esvaziado de ambições políticas e de função crítica.

Os longos dentes e a língua bifurcada do bicho, experimentando seu refúgio, provocaram a primeira ponta de dor. Quando a cabeça penetrou em sua metade, escorreu um filete de sangue que formou uma pequena poça na altura do joelho. A carne da moça tremia como um todo, o suor frio transformava sua pele numa superfície pegajosa. As escamas da surucucu lanhavam interna e externamente, pintando as coxas com manchas vermelhas. Só o tronco de cipó agora aparecia, como uma cauda histérica da própria Regina, oscilante como a do cão acariciado.

O das luvas segurou o ofídio pela ponta e empurrou-o para dentro, ajudando-o a se abrigar. A parte visível do imenso verme já estava coberta de um sangue grosso, adolescente. O homem levantou parcialmente a cobra e, colocando a mão por baixo, fez cócegas em seu ventre. Do meio do peito da menina saiu um grunhido fundo, um assobio, Regina gania seu suplício. A surucucu já desaparecera até o meio, e se acomodava entre os irmãos intestinos. A mordaça se tingia de sangue. O queixo pendia inerte, tocando as cordas. Os três homens gargalhavam suas doenças. (MARTINS, 1977, p. 21).

A gradação progressiva construída pela descrição do método de tortura empregado contra a vítima atinge o seu clímax nos dois últimos parágrafos acima citados. Violência e sadismo atingem, aí, o seu ponto máximo, precipitando, depois, um desfecho disfórico em que, como dissemos, a perversidade triunfa sobre a inocência - o mal se afirma em triunfantes gargalhadas. O traço realista-naturalista empregado na descrição da tortura intensifica o efeito de choque produzido pelo conto, inscrevendo-o no campo do sensacional. Este é mais um dado que confirma certa limitação de seu alcance crítico. O método nele descrito situa a violência da tortura no campo do excepcional, do monstruoso - dois traços fortes do apelo sensacionalista. Acresce-se a isso o fato de que este método de tortura e assassinato é uma espécie de paródia demoníaca da defloração de uma virgem no ato sexual, equivalendo a um estupro dantesco que articula violência e sexo. Ora, o sensacionalismo é, tanto no jornalismo quanto na literatura realista-naturalista, o elemento que favorece um esvaziamento das implicações sociais, políticas, históricas e/ou culturais do fato narrado - dado eviden- 
te, segundo Barthes (2007), no fait divers ${ }^{3}$, a notícia miúda, e em determinadas expressões do naturalismo brasileiro nos séculos XIX e XX (Aluísio Azevedo e Nelson Rodrigues, p. ex. ${ }^{4}$ ). Como se dá este esvaziamento? Fundamentalmente pelo tratamento conferido ao fato relatado como algo que se situa exclusivamente na esfera individual dos envolvidos. Deste modo, o crime ganha foros de excepcionalidade, de monstruosidade, de loucura ou perversão, de maldade, enfim, em razão de serem obliterados os seus vínculos com a sociedade em que se manifesta, e o criminoso, compreendido sob os rótulos do monstro, do louco, do perverso, converte-se numa encarnação do mal: depois de supliciarem Regina com uma cobra surucucu, os "homens gargalhavam suas doenças".

"O método" narra de modo esquemático a curta sequência de ação dramática que converte em história narrada. O esquematismo o aproxima da estrutura do sketch, mas com a distinção de pretender suscitar, pelo impacto da descrição da tortura e de seus efeitos, o horror ${ }^{5}$. A curta extensão do conto e o esquematismo que caracteriza a construção da história narrada reforçam o apoio em clichês - construção de personagens tipo que tendem à estereotipia; redução do conflito dramático ao maniqueísmo; supressão de dados que permitissem uma contextualização histórica mais efetiva da história narrada; emprego de clichês para caracterizar o espaço em que ocorre a ação dramática (o porão escuro, sujo, malcheiroso) - que limitam o alcance crítico e a possível contundência política do texto, que desloca fortemente para a recepção a tarefa de contextualizar histórica e politicamente aquilo que lê.

Considerados o seu contexto imediato de produção e recepção, $2^{\text {a }}$ metade dos anos 1970, sua inclusão na coletânea Histórias de um novo tempo a partir da qual ele alcançou

3 Segundo Barthes, "o fait divers [...] é uma informação total, [...] imanente; ele contém em si todo seu saber: não é preciso conhecer nada do mundo para consumir um fait divers; ele não remete formalmente a nada além dele próprio; evidentemente, seu conteúdo não é estranho ao mundo: desastres, assassínios, raptos, agressões, acidentes, roubos, esquisitices, tudo isso remete ao homem, a sua história, a sua alienação, a seus fantasmas, a seus sonhos, a seus medos [...]; no nível da leitura, tudo é dado num fait divers; suas circunstâncias, suas causas, seu passado, seu desenlace; sem duração e sem contexto, ele constitui um ser imediato, total, que não remete, pelo menos formalmente, a nada de implícito [...]. É sua imanência que define o fait divers (2007, p. 57-58).

4 Veja-se, por exemplo, o episódio da personagem Pombinha em O cortiço, que encarna a "tese" de que se contrariado o impulso sexual natural, dele resulta uma sexualidade degenerada. Pombinha passa de virgem do cortiço a mulher de sexualidade desregrada. No caso de Nelson Rodrigues, é recorrente em sua obra a "tese" de que a degeneração sexual e moral da família patriarcal decorre invariavelmente de uma falha moral do pai patriarca - o que projeta, por efeito de choque e inversão, nas obras do autor, a ideia de que a família patriarcal, com toda a sua hierarquia calcada em moralismo, repressão sexual e hierarquia machista, é um ideal inquestionável mesmo que o pai patriarca falhe, pois é a sua falha que a obra de Rodrigues castiga, explorando o que estabelece como os efeitos dessa falha (incesto; sexualidade degenerada; homossexualidade; desregramento sexual e moral). Esta tese é, aliás, o fundamento da dramaturgia e das principais narrativas rodriguianas.

5 Em Literatura e vida literária (1985), Flora Sussekind faz uma crítica ao que acredita ser "uma marcante preferência do público literário brasileiro pelos tristes e detalhados relatos de torturas, perseguições policiais e confinamentos [...] Essa ávida leitura da experiência carcerária ou da narrativa dos sofrimentos alheios parece apontar no sentido de um grande mea culpa da classe média que apoiou o golpe militar de 1964 e a subseqüente militarização da sociedade brasileira e, desencantada, começa a se penitenciar ficcionalmente pela repetida leitura de suas consequências. Ou, caminho inverso, trata-se de uma outra geração de leitores cujo conhecimento da história recente do país, fragmentário e contraditório, se procura ordenar e reinterpretar com base nas versões não oficiais a que se começa ter acesso com o aparecimento de um volume maior de publicações de depoimentos, memórias e romances políticos. O que ocorre sobretudo a partir de 1975. E, de maneira acentuada, depois da anistia, já no Governo Figueiredo". (SUSSEKIND, 1985, p. 44). 
um maior número de leitores, e, também, a idade com que o autor o escreveu e publicou (entre 19 e 21 anos), torna-se compreensível a ênfase no objetivo de chocar por efeito de uma denúncia calcada na descrição da tortura em "O método".

A ausência de dados que permitam uma contextualização histórica mais precisa parece ambicionar aproximar a história narrada em "O método" de um efeito kafkiano segundo o qual o horror se encontraria tão profundamente naturalizado que se universalizaria, virtualmente, como risco para qualquer um que pudesse ser tomado como vítima de sádicos amparados institucional ou para-institucionalmente pela ditadura civil-militar. O problema é que tal ausência de dados passíveis de contextualização histórica mais efetiva cria uma ambiguidade incômoda, fazendo com que o conto fragilize a possibilidade de vincular o horror narrado à ação repressiva da ditadura civil-militar. Se isto é dado como pressuposto na relação entre o conto e seu contexto imediato de produção e recepção, fica, num contexto posterior, fragilizado, requerendo do leitor um repertório e um comportamento, uma leitura, enfim, que lhe permita resgatar dados para efetivar a contextualização histórica do texto.

Por fim, observe-se que o recurso a um narrador de $3^{\text {a }}$ pessoa com foco narrativo narrador onisciente neutro (FRIEDMAN, 2002, p. 174-175), que dá ênfase ao mostrar, estabelece um distanciamento entre aquele que narra e a história narrada. Se, por um lado, estes recursos de distanciamento concorrem para uma naturalização do horror mostrado, por outro lado enfraquecem o horror que pretendem produzir exatamente por efeito de tal naturalização, que circunscreve a história narrada, como já dito, nos campos do monstruoso, do excepcional e do sensacional.

\section{“A POSIÇÃO” E A IMAGINAÇÃO DO HORROR}

O conto "A posição" foi publicado no livro Sabe quem dançou?, de 1978. Neste conto, um narrador de $1^{\text {a }}$ pessoa conta a história da morte de seu amigo Pedro, torturado e assassinado. A tortura e a morte, aqui, são imaginadas por este narrador - o que confere peso dramático a seu exercício de imaginação, pois, ao realizá-lo, ele se revela também uma vítima dos efeitos dessa tortura que resultou em assassinato.

A fábula do conto é simples: um narrador nos conta que seu amigo, Pedro, morreu após sofrer tortura, imaginando, ao narrar, como o amigo teria vivido a sua agonia.

O ângulo de visão com que a história é narrada (narrador de $1^{\text {a }}$ pessoa) indica que o narrador conta de sua perspectiva individual, mesmo quando oferece, na narrativa, dados que parecem resultar de uma posição onisciente. Além disso, o recurso à primeira pessoa confere à história narrada o estatuto de um testemunho, colocando em primeiro plano não apenas o horror sofrido por Pedro na tortura mas também o sofrimento daquele que o imagina e narra.

Meu amigo Pedro morreu de cabeça para baixo, como uma galinha ou uma fruta madura. 
Seus pés estavam amarrados por uma corda grossa, que se prendia a um gancho no teto. Suas mãos estavam atadas e quase tocavam o soalho.

Pedro estava nu, e seu corpo longo e nobre parecia uma estátua de um prédio em demolição.

Vez por outra Pedro era balançado como um pêndulo, a marcar ele mesmo seus segundos de agonia.

Sua cara estava vermelha.

Seus pés estavam brancos (MARTINS, 1978, p. 117).

No início do conto, acima citado, observa-se um deslizamento da $1^{\text {a }}$ pessoa ("Meu amigo Pedro morreu...") para uma aparente $3^{\text {a }}$ pessoa que narrará de modo supostamente mais objetivo como se deu a morte de Pedro. Por meio deste recurso, instala-se, na narração, um aparente distanciamento entre a história narrada e aquele que narra, recurso que torna possível a narração do horror, configurando um testemunho de $2^{\circ}$ grau, já que o narrador não viveu o horror que narra, mas sofre os seus efeitos.

Toda a descrição do corpo - sua posição, os detalhes que o singularizam na posição em que se encontra, indicando os efeitos da tortura (corpo alongado; cara vermelha; pés brancos) - é efetuada a partir deste deslizamento de uma $1^{\text {a }}$ pessoa para uma aparente $3^{\text {a }}$ pessoa. O distanciamento, porém, é interrompido para ceder lugar à imaginação do narrador de $1^{\text {a }}$ pessoa nos dois parágrafos finais do trecho citado - fato que o final deste primeiro trecho do conto confirmará: "[...] foi bom que eu não estivesse ao lado dele quando tudo aconteceu” (MARTINS, 1978, p. 117). Na caracterização do corpo de Pedro já se manifesta uma descrição resultante do exercício de imaginação do narrador, o que colocará em primeiro plano o seu próprio sofrimento:

A dor começou nas pernas, e foi tomando a coluna e a cabeça como se fosse uma água que escorresse.

O chão se aproximava na medida em que as vértebras se afastavam umas das outras.

Enquanto pendia, Pedro só conseguia pensar

que sua mulher, sua mãe e seus filhos estariam vomitando desespero àquela hora.

que foi bom que eu não estivesse ao lado dele quando tudo aconteceu.

que havia a lei da gravidade. 
que talvez ela não fosse a única.

que ele precisava de uma ambulância e de um médico.

que ele não tinha instituto.

que ele seria notícia em todos os jornais do dia seguinte.

que ele não seria notícia em jornal algum.

que ele gostaria de ser um elástico.

que ele gostaria de não ser.

que ele talvez não fosse mais.

que há meses estava naquela posição.

que talvez alguém pintasse ou escrevesse tudo aquilo.

que lá fora chovia.

que não adianta represar os rios, se não se pode parar a chuva (MARTINS,1978, p. 118).

Embora testemunha de $2^{\circ}$ grau, o narrador se aproxima do lugar do sobrevivente. Não o sobrevivente que confere efeito de verdade a seu testemunho porque viveu na carne o horror que narra, mas aquele que, tendo partilhado de uma experiência comum, teve a sorte de escapar do mesmo destino funesto. O enunciado "que foi bom que eu não estivesse ao lado dele quando tudo aconteceu" em que o narrador assume, interpretando, a voz do outro, põe todos os dados enumerados entre a voz do heroi e a do narrador, o que prova a partilha da mesma experiência ainda que pela sugestão de um relato da vítima, o qual, não tendo de fato ocorrido, torna-se possível pela projeção e ocupação do lugar do outro, modo de manifestar o sofrimento do outro pela manifestação de quem testemunha essa transposição de lugares.

A enumeração dos possíveis pensamentos de Pedro na posição em que fora colocado constrói uma gradação progressiva cuja função é, pois, simultaneamente, representar a dor do torturado e o sofrimento daquele que sabe que poderia estar junto do amigo, compartilhando do mesmo destino. Há uma espécie de dupla filtragem, digamos assim, que caracteriza a representação da tortura neste trecho em que os possíveis pensamentos de Pedro são imaginados pelo narrador, e ela intensifica o efeito dramático do conto, reduplicando a dor e pondo o leitor no circuito desse diálogo. Não há, aqui, ênfase na descrição realista-naturalista da tortura tal como aquela realizada em "O método", mas investimento numa subjetivação do horror que põe em primeiro plano os seus efeitos sobre as vítimas de $1^{\circ}$ e $2^{\circ}$ graus (o que, neste último caso, inclui o leitor). 
Construindo um paralelismo, o narrador contrapõe à enumeração dos possíveis pensamentos de Pedro uma enumeração de fatos externos e simultâneos à sessão de tortura:

Isso eram pensamentos que se justapunham na cabeça de Pedro, como automóveis em um grande engarrafamento. Mas Pedro não sabia

que sua mãe havia morrido na noite anterior.

que lá fora era sol quente.

que fazia pouco mais de doze horas que estava naquela posição.

que jamais sairia vivo daquela posição.

que ninguém sabia onde ele estava.

que, no fundo, todos sabiam onde ele estava.

que seus pés já estavam podres, por falta de circulação.

que seu pênis estava ereto, com o sangue concentrado.

que era o dia da partida final do Campeonato.

que todos torciam pelo seu time.

que eu escreveria esta história.

que ele fedia como um porco selvagem.

que um de seus olhos havia saltado da órbita.

que tudo não passaria de suicídio por remorso.

que seu sangue sofreria o mesmo milagre dos pães (MARTINS, 1978, p. 118119).

Destaque-se, inicialmente, a oposição entre o enunciado atribuído a Pedro na série enumerativa anterior - enquanto pendia, "Pedro só conseguia pensar / que sua mulher, sua mãe e seus filhos estariam vomitando desespero àquela hora" (MARTINS, 1978, p. 118 grifos nossos) - e o enunciado assumido pelo narrador na presente série enumerativa: "Mas Pedro não sabia / que sua mãe havia morrido na noite anterior" (MARTINS, 1978, 118 -grifos nossos). Com a incompatibilidade entre o que Pedro supostamente pensava e o que já 
não sabia, intensifica-se o drama descrito.

No que se refere à enumeração daquilo que Pedro não sabia, cria-se ainda um contraste entre o sofrimento da vítima, que perde inclusive a consciência do próprio corpo, e a indiferença do mundo ("lá fora era sol quente"; "ninguém sabia/todos sabiam onde ele estava"; "era o dia da partida final do Campeonato"). Destacamos, aqui, os elementos que constituem os dois últimos enunciados desta enumeração. No primeiro caso, a afirmação "tudo não passaria de suicídio por remorso" alude, ironicamente, às explicações oficiais para "suicídios" que teriam sido cometidos por suspeitos de subversão quando de seu interrogatório por autoridades policiais e/ou militares - dos quais o mais famoso foi o do jornalista Vladimir Herzog. No segundo caso, a referência ao milagre da multiplicação dos pães ganha foros de ironia amarga, antecipando o final terrível da vítima.

A própria caracterização do corpo de Pedro nesta segunda série de enumerações é imaginária. O deslocamento do plano do registro realista-naturalista para o plano do registro imaginário sublinha, em termos de representação, o sofrimento daquele que sobreviveu a uma morte que bem poderia ter sido a sua. O sofrimento, a angústia e a impotência deste, digamos assim, sobrevivente de $2^{\circ}$ grau redobram, em intensidade, os efeitos da tortura e do assassinato político, revelando que seu alcance transcende os limites individuais da vítima, marcando a própria sociedade. Passa-se, portanto, da esfera do horror individualmente vivido pela vítima para uma constatação de que tal horror se configura como risco a qualquer membro da sociedade que o instituiu. Converte-se, deste modo, a vivência individual (erlebnis) em experiência comum (erfarhung), para usarmos aqui de um ensinamento de Walter Benjamin (1986) em seu ensaio sobre o narrador.

Imaginada é também a sequência que resultará na morte de Pedro:

Alguém sugeriu que se amarrasse um paralelepípedo na cabeça do Pedro. Um paralelepípedo é um cubo de granito. Granito é uma matéria de outra densidade da que estava pendurada. E outro alguém pensou em jogar água para que o homem acordasse. A água, de densidade oposta à do granito, foi lembrada por ser de temperatura mais amena. E outro mais advertiu que o homem estava morrendo, e que não havia interesse nenhum na sua morte. Da morte desconheço mais que tudo a densidade, temperatura e volume.

Há meia hora Pedro havia parado de escutar as vozes. A saliva cremosa que escorria de sua boca encontrava as raízes dos cabelos.

Sua cara estava roxa.

Seus pés estavam roxos.

Os homens então tomaram ciência de que ele estava mesmo morrendo. Um deles subiu numa escada, segurando o corpo de Pedro pela cintura, e virou-o repentinamente para a posição normal. 
Foi quando a cabeça de meu amigo Pedro explodiu como uma bomba (MARTINS, 1978, p. 119).

A reconstituição imaginária do que teria ocorrido na sessão de tortura que resultou em morte da vítima intensifica o impacto da violência e o efeito de horror daquilo que é narrado. O sadismo dos torturadores é reforçado na possível sugestão, feita por um deles, "de que se amarrasse um paralelepípedo na cabeça do Pedro" (note-se que o uso de "do", aí, sublinha o laço afetivo entre o narrador e a vítima). O pensamento, também imaginado, de outro dos torturadores de jogar água para "que o homem acordasse" se integra aos possíveis suplícios infligidos à vítima. A suposta advertência de que Pedro estava morrendo e que "não havia interesse nenhum na sua morte" confere à tortura relatada o estatuto de prática rotineira, institucionalizada. A descrição imaginada do corpo no final - "saliva cremosa [...] escorria de sua boca"; "Sua cara estava roxa"; "Seus pés estavam roxos" - recupera, via paralelismo, o corpo supliciado inicialmente imaginado pelo narrador, indicando sua morte iminente. O mais importante de tudo o que aí é imaginado é a constatação de que a tortura e a morte dela resultante são evidências de um mal naturalizado na rotina de trabalho dos que as perpetram - dado evidente na ação final de virar repentinamente o corpo de Pedro, produzindo a sua morte.

A morte também é, no final do conto, objeto da especulação imaginária do narrador. Observe-se:

foi quando meu amigo Pedro reuniu suas últimas forças para cuspir bem no meio daquela cara inexpressiva que o fitava.

$\mathrm{Ou}$

foi o tempo que sobrou para que o meu amigo Pedro perguntasse a quem pudesse ouvir sua débil voz: "Será que vocês têm filhos?"

$\mathrm{Ou}$

foi quando o seu cérebro esvaiu junto com o sangue uma última e muda ideia, de que findando ele ou todos os homens, tudo continuaria a ser muito relativo.

$\mathrm{Ou}$

foi quando ele percebeu uma sensível melhora, e calou-se. Sem saber que metade de seu corpo já havia apodrecido. Sem imaginar a discreta espreita de todos

os insetos.

$\mathrm{Ou}$ 
foi quando ele sentiu-se desatado, e carregando as sobras de vida das suas mãos ao seu próprio pescoço, terminou o serviço que os homens deixaram incompleto. Assim era Pedro, acostumado à competência. E assim Pedro era, que nada deixava incompleto (MARTINS, 1978, p. 119-120).

A enumeração das possíveis ações de Pedro quando, recolocado abruptamente em posição normal, se aproxima da morte põe em relevo as reações do narrador diante da morte do amigo. Na comparação "explodiu como uma bomba" insinua-se uma hipérbole que sugere a intensidade da dor do narrador diante da morte de Pedro e, a partir daí, a reconstituição imaginária dessa morte dá expressão àquilo que o narrador experimenta ante ela: a) sede de vingança ao imaginar que Pedro cuspira na "cara inexpressiva que o fitava"; b) indignação e espanto ao imaginar que Pedro interpelara seus algozes perguntando se tinham filhos (ao apelar para sua suposta humanidade, ele os revelaria, na verdade, desumanos); c) ironia amarga ao imaginar que Pedro constataria uma eterna relatividade de tudo ante sua própria morte (modo de afirmar que esta morte individual pouco alteraria a vida dos outros e do mundo) ou, então, que ignoraria o efeito fatal da tortura sobre seu corpo já semi-apodrecido ou, ainda, que completaria o processo iniciado pelos torturadores se auto-esganando.

Da tortura e da morte efetivas de Pedro, o narrador sabe concretamente pouco. Ele dá expressão ao sofrimento do amigo por meio da colocação em primeiro plano de seu próprio sofrimento ao imaginar a tortura e a morte de Pedro. Ao fazê-lo, convoca o leitor a comover-se com aquilo que, só podendo imaginar, narra. Observe-se que a imaginação, aí, não é fonte de alívio para o sofrimento. Se, por um lado, ela permite que o sobrevivente elabore narrativamente a dor, construindo uma versão para o horror da violência que indiretamente o atingiu, por outro lado ela evidencia uma impossibilidade de conferir à narração realizada o estatuto de um luto libertador. A história narrada em "A posição" é, neste sentido, fruto de um processo melancólico6 que é constitutivo do narrador, revelando, com isso, a sua própria condição de vítima. A maior evidência de tal processo melancólico são as enumerações nas quais o narrador se apoia para imaginar o que narra. É por meio delas que se torna possível para o narrador relatar o horror instalado num horizonte de experiência comum entre ele e seu amigo. Este horror vitimou a ambos, mas, no seu caso, a ferida produzida permanece aberta. É por isso que, no final, ele faz referência ao tempo, fundindo-o à imagem inicial com que caracteriza a posição do corpo supliciado de Pedro: "E nada deixou incompleto, pois o tempo é o melhor dos complementos. / Mesmo um tempo que morre de cabeça para baixo, como uma galinha ou/ uma fruta madura." (MARTINS, 1978, p. 120).

A alteração do dito popular - O tempo é o melhor dos remédios - se associa à melancolia do narrador. A substituição de "remédios" por "complementos" indica, no enunciado, que a dor do narrador não terá alívio. A fusão das imagens do tempo e do corpo inerte de Pedro "como uma galinha ou uma fruta madura" se presta a uma avaliação que estende o horror do segundo para o primeiro, caracterizando-o. Esse tempo que morre é o melhor complemento. Eis o ponto de chegada, mas não o ponto final. Trata-se, por efeito de suges-

6 Da leitura de "Luto e melancolia", de S. Freud (1992), pode-se concluir que a melancolia se caracteriza como um processo de luto incompleto, marcado pela recusa do melancólico em concluir o luto apesar da consciência que tem de sua perda. Essa recusa produz um contínuo retorno à situação de perda, renovando o sofrimento a ela vinculado. 
tão, de um tempo cíclico - dado reforçado exatamente pela repetição que, unindo início e fim da narrativa, funde as imagens do corpo supliciado de Pedro ao tempo.

A diferença fundamental entre a melancolia e o luto no trato com o objeto libidinal perdido, segundo Freud (1992), é que no final do processo de luto se dá uma nova abertura para a vida por efeito da assunção de que o objeto perdido está, de fato, perdido - pela morte, por exemplo. Ou, no caso da ruptura amorosa, pela assunção de que o amor perdido está, de fato, perdido e não retornará. Quanto à melancolia, ela implica necessariamente um processo que não se conclui porque o melancólico é um sujeito que se recusa a admitir a perda do objeto libidinal. Neste sentido, o melancólico nunca elabora a perda a ponto de concluir um processo de luto. Ele permanece fixado na recusa à admissão da perda como algo irremediável, e esta fixação faz com que ele mantenha vivo, para si (em seu processo psíquico), o objeto perdido. Esta síntese da reflexão freudiana sobre o luto e a melancolia, ainda que redutora, nos ajuda a compreender um aspecto fundamental de "A posição": a melancolia constitutiva de seu narrador; a morte de Pedro como complemento que permanece.

O narrador de "A posição" sobrevive à tortura e à morte de seu amigo Pedro, sofrendo, como uma vítima de $2^{\circ}$ grau, os efeitos desta tortura e desta morte. Paradoxalmente, ao narrar, ele dá ao amigo uma nova vida e uma nova morte, ou seja: ao transformar Pedro em personagem da história de tortura e morte que imagina e narra, ele as re-atualiza. Esta reatualização, via imaginação e narrativa, faz com que Pedro re-viva e re-morra. Isso, articulado com a enumeração de possibilidades que revelam, na verdade, o sofrimento do narrador em suas cogitações sobre a tortura e a morte do amigo, nos mostra que ele sofre uma dor que não tem alívio. Não há luto possível, portanto, mas processo melancólico: o narrador sobreviveu à morte brutal do amigo, mas carrega em si a angústia e a dor por ter sobrevivido. Narrar esta morte e o processo que levou a ela não parece ser suficiente para produzir um luto libertador. Ao contrário, a história narrada e, principalmente, a narração evidenciam que a angústia e a dor permanecem - o que sublinha a melancolia.

Os procedimentos aqui destacados na análise da narração de "A posição" mostram um amadurecimento do autor na escrita do $1^{\circ}$ para o $2^{\circ}$ contos aqui estudados. Ao propósito de chocar por meio da ênfase na descrição do método de tortura empregado para assassinar a vítima, no primeiro conto, contrapõe-se uma abordagem dos efeitos de uma morte brutal sobre aquele que, sem esquecê-la, a ela sobrevive. A descrição da tortura, no segundo conto, está subordinada à exposição do sofrimento do narrador que sobreviveu à perda de seu amigo. Esta subordinação é o que garante um deslocamento da ênfase na descrição, elemento ainda forte em "A posição", para uma ênfase no sofrimento do sobrevivente - dado que permite entrever a sua impotência diante do ocorrido. O efeito de horror, no segundo conto, não se dilui, dificultando a recepção perversa.

\section{CONSIDERAÇÕES FINAIS}

O problema da representação da tortura nos dois contos analisados nos permite observar a injunção da dimensão ética sobre a dimensão estética no caso da representação do extremo. A tortura, assim como o corpo morto ou degradado, é um extremo vincado pela 
violência e sua representação impõe questões éticas para os usos que um escritor ou artista faz de seu material de trabalho.

No caso da literatura, os procedimentos por meio dos quais a representação da tortura ganha corpo numa obra passam pelo desafio do saber equilibrar o narrar e o mostrar e, sobretudo, saber fazer uso da descrição evitando reduzi-la a fim em si mesma. Isso impõe ao artista, na sintaxe da obra criada, o desafio de subordinar a descrição da tortura a uma outra função que cumpra, na interação com o leitor/espectador, a tarefa de crítica e de sensibilização para o horror, evitando que ele se converta em divertimento. Em "O método" o propósito de denunciar o horror por meio da ênfase na descrição caminha no fio da navalha, arriscando que, no plano da recepção, abra-se espaço para uma recepção perversa, sádica, da história do supliciamento gratuito de uma jovem por seus torturadores. Já em "A posição" a subordinação da descrição da tortura à imaginação do narrador põe em primeiro plano, também, a dor daquele que, tendo escapado do funesto destino do amigo, sobreviveu e não esquece - o que intensifica o impacto e a força de denúncia que o conto tem.

\section{REFERÊNCIAS BIBLIOGRÁFICAS}

AZEVEDO, A. O cortiço. São Paulo: Ática, 1979.

BARTHES, R. Estrutura da notícia. In: . Crítica e verdade. 3. ed. São Paulo: Perspectiva, 2007. p. $57-67$.

BENJAMIN, W. O narrador: considerações sobre a obra de Nikolai Leskov. Trad. Sérgio Paulo Rouanet. In: ___. Magia e técnica, arte e política: ensaios sobre literatura e história da cultura (Obras escolhidas, v. 1). São Paulo: Brasiliense, 1986. p. 197-221.

CANDIDO, A. A nova narrativa. In: . A educação pela noite e outros ensaios. São Paulo: Ática, 1989. p.199-217.

CUNHA, L. C. A repórter pergunta e o ministro gagueja. Observatório da Imprensa, 19 ago. 2014. Disponível em: http://www.observatoriodaimprensa.com.br/educacao-e-cidadania/caderno-dacidadania/_ed812_a_reporter_pergunta_o_ministro_gagueja/. Acesso em: 08 ago. 2020.

FAVERO, D. Insetos em genitália e éter eram formas de tortura. Portal Terra, 10 dez. 2014. Disponível em: https://www.terra.com.br/noticias/brasil/insetos-em-genitalia-e-eter-eram-formas-de-tortura,5b0 b4810e653a410VgnVCM4000009bcceb0aRCRD.html. Acesso em: 08 ago. 2020.

FREUD, S. Luto e melancolia. Trad. Marilene Carone. Novos Estudos - CEBRAP, São Paulo, n. 32, p. 128-142, 1992. Disponível em http://novosestudos.uol.com.br/v1/files/uploads/contents/66/20080625_ luto_e_melancolia.pdf. Acesso em: 21 mar. 2019.

FRIEDMAN, N. O ponto de vista na ficção. Trad. Fábio Fonseca de Melo. Revista USP, São Paulo, s/v, 
n. 53, p. 166-182, 2002. Disponível em http://www.revistas.usp.br/revusp/article/view/33195/35933. Acesso em: 05 ago. 2015.

MARTINS, J. C. M. O método. In: ; ABREU, C. F.; ANDRADE, J. R.; BARRETO, A.; EMEDIATO, L. F.; PELLEGRINI Jr., D. Histórias de um novo tempo - o novíssimo conto brasileiro. Rio de Janeiro: Codecri, 1977. p. 19-21.

A posição. In: Sabe quem dançou?. Rio de Janeiro: Codecri, 1978. p. 117-120.

RODRIGUES, N. Teatro Completo. Rio de Janeiro: Nova Fronteira, 1982/1984.

SÜSSEKIND, F. Literatura e vida literária - Polêmicas, diários \& retratos. Rio de Janeiro: Zahar, 1985.

TELES, M. A. A. Violações dos direitos humanos das mulheres na ditadura. Revista Estudos Feministas, Florianópolis, v. 23, n. 3, p. 1001 - 1022, 2015. Disponível em: https://www.scielo.br/pdf/ ref/v23n3/0104-026X-ref-23-03-01001.pdf. Acesso em 08 ago. 2020. 
